\title{
Problem Based Learning (PBL) activity for delivering Vehicle Dynamics
}

\author{
Shirish Subhash Mane ${ }^{1}$ \\ ${ }^{1}$ Automobile Engineering Department, Rajarambapu Institute of Technology, Sakharale \\ ${ }^{1}$ shirish.mane@ ritindia.edu
}

\begin{abstract}
Vehicle Dynamics is one of the core courses offered to Automobile engineering students in their curriculum at most of the Indian universities. Earlier this course was delivered using traditional classroom delivery method with exam based approach to evaluate students. This paper aims to study the use of Problem Based Learning (PBL) as a tool to engage students actively in the teaching learning process and also evaluate them throughout the semester for in-semester evaluation. The students were asked to work in groups and complete activities which are given to them in the form of problems to depict real life problems that the vehicle has to encounter. Finally, students were made to submit a report and present their findings to the whole class.

An evaluation rubric was also developed to grade the students. It was designed in such a way that it takes into account all the components of the learning which the students are expected to learn as an outcome of the course. Also, the activities to be performed are designed considering the learning outcomes specified by ABET and graduate attributes specified by NBA.
\end{abstract}

Keywords: Problem Based Learning, learning outcomes, activities.

\section{Introduction}

There is a huge requirement of skilled engineers across the world. Internationally there is a trend moving towards outcome based engineering education. New accreditation models focus on outcome based learning. The national academies and many governments call for change in engineering education (Litzinger et al, 2011). In India, engineering education is under pressure as professional engineering bodies and Indian industries call for additional set of skills and competencies such as professional, soft and personal skills (Blom and Saeki, 2009, Goel, 2006). To meet the demand of skilled engineers, the capacity of engineering educational institutions in India were increased by increasing the capacity of existing colleges and by establishing new colleges. It has resulted in an increase in the volume, but the quality of the graduate engineer is still uncertain (Rao, 2006). Also, various government reports indicated the genuine concern about the quality of an engineering education pointing towards the need for radical changes in the curriculum and the teaching-learning practices in India.

Given this situation, Problem Based Learning (PBL) is considered as relevant (Shinde, 2011b) and suitable alternative as the past results shown that if properly designed and implemented PBL leads to the development of industry relevant skills and prepare students for lifelong learning (Du and Kolmos, 2006, Shinde and Kolmos, 2011a). Problem Based Learning has its origin in McMaster University Canada in 1968. Later in Denmark at Aalborg, 1972 and Roskilde, 1974 two PBL models emerged. These models are designed from scratch (Graaff and Kolmos, 2003). Also, culture in these countries is different from India. Indian education systems are built for traditional teaching i.e. instruction based pedagogy. Hence, it is necessary to develop PBL model suitable for Indian conditions. Also, challenge is to achieve learning outcomes and skills demanded by the industries and prescribed by NBA and ABET. The objective of this paper is to discuss the development process of a PBL activity and its evaluation process at course level to evaluate the students as a part of In Semester Evaluation (ISE).

\section{Methodology}

A. Program outcomes specified by National Board of Accreditation (NBA)

In response to the recent developments in Higher education in India and across the world; the Ministry of Higher Education in India has decided to change the accreditation criteria to become outcome based. India, being a member of the Washington Accord, applies Accreditation Board for Engineering and Technology, [ABET] criteria 2019-20 to assess the quality of education in educational institutes. Table 1 shows a summary of the Program Outcomes of a formal engineering program in India as specified by NBA. Since, NBA is the apex body which ensures quality education is imparted in India, these criteria are critically considered for the problem based learning design.

These outcomes specify the knowledge, skills and attributes any engineer should possess at the end of his/her 
engineering program for any formal engineering program that the student undergoes in India.

Table 1: Summary of POs as specified by NBA for engineering programs in India

\begin{tabular}{|c|c|}
\hline $\begin{array}{c}\text { Program } \\
\text { Outcome } \\
\quad(\mathrm{PO})\end{array}$ & Statement of Program Outcome \\
\hline 1 & $\begin{array}{l}\text { An ability to apply the knowledge of } \\
\text { mathematics, science, engineering } \\
\text { fundamentals, and an engineering } \\
\text { specialization to the solution of complex } \\
\text { engineering problems. }\end{array}$ \\
\hline 2 & $\begin{array}{l}\text { An ability to identify, formulate, review } \\
\text { research literature, and analyse complex } \\
\text { engineering problems reaching } \\
\text { substantiated conclusions using first } \\
\text { principles of mathematics, natural sciences, } \\
\text { and engineering sciences. }\end{array}$ \\
\hline 3 & $\begin{array}{l}\text { An ability to design solutions for complex } \\
\text { engineering problems and design system } \\
\text { components or processes that meet the } \\
\text { specified needs with appropriate } \\
\text { consideration for the public health and } \\
\text { safety, and the cultural, societal, and } \\
\text { environmental considerations }\end{array}$ \\
\hline 4 & $\begin{array}{l}\text { An ability to use research-based knowledge } \\
\text { and research methods including design of } \\
\text { experiments, analysis and interpretation of } \\
\text { data, and synthesis of the information to } \\
\text { provide valid conclusions. }\end{array}$ \\
\hline 5 & $\begin{array}{l}\text { An ability to create, select, and apply } \\
\text { appropriate techniques, resources, and } \\
\text { modern engineering and IT tools including } \\
\text { prediction and modeling to complex } \\
\text { engineering activities with an } \\
\text { understanding of the limitations. }\end{array}$ \\
\hline 6 & $\begin{array}{l}\text { An ability to apply reasoning informed by } \\
\text { the contextual knowledge to assess societal, } \\
\text { health, safety, legal and cultural issues and } \\
\text { the consequent responsibilities relevant to } \\
\text { the professional engineering practice. }\end{array}$ \\
\hline 7 & $\begin{array}{l}\text { An ability to understand the impact of the } \\
\text { professional engineering solutions in } \\
\text { societal and environmental contexts, and } \\
\text { demonstrate the knowledge of, and need for } \\
\text { sustainable development. }\end{array}$ \\
\hline 8 & $\begin{array}{l}\text { An ability to apply ethical principles and } \\
\text { commit to professional ethics and } \\
\text { responsibilities and norms of the } \\
\text { engineering practice. }\end{array}$ \\
\hline 9 & $\begin{array}{l}\text { An ability to function effectively as an } \\
\text { individual, and as a member or leader in } \\
\text { diverse teams, and in multidisciplinary } \\
\text { settings. }\end{array}$ \\
\hline 10 & $\begin{array}{l}\text { An ability to communicate effectively on } \\
\text { complex engineering activities with the } \\
\text { engineering community and with society at } \\
\text { large, such as, being able to comprehend } \\
\text { and write effective reports and design }\end{array}$ \\
\hline
\end{tabular}

\begin{tabular}{|l|l|}
\hline \multirow{2}{*}{11} & $\begin{array}{l}\text { documentation, make effective } \\
\text { presentations, and give and receive clear } \\
\text { instructions. }\end{array}$ \\
\hline $\begin{array}{l}\text { An ability to demonstrate knowledge and } \\
\text { understanding of the engineering and } \\
\text { management principles and apply these to } \\
\text { one's own work, as a member and leader in } \\
\text { a team, to manage projects and in } \\
\text { multidisciplinary environments. }\end{array}$ \\
\hline 12 & $\begin{array}{l}\text { An ability to recognize the need for, and } \\
\text { have the preparation and ability to engage } \\
\text { in independent and lifelong learning in the } \\
\text { broadest context of technological change. }\end{array}$ \\
\hline
\end{tabular}

\section{B. Course Level Requirements}

Rajarambapu Institute of Technology is an autonomous institute affiliated to Shivaji University, Kolhapur. Being an autonomous institute, it has the authority to modify the curriculum as per need of industry. The evaluation of the students is divided into three parts. In Semester Evaluation, Unit Tests and End Semester Evaluation, Table 2 shows the distribution of marks for these three parts.

Table 2. Evaluation Scheme and weightage

\begin{tabular}{|c|c|}
\hline \multicolumn{1}{|c|}{ Table 2. Evaluation Scheme and weightage } \\
\hline Mode & Marks \\
\hline ISE & 20 \\
\hline Unit Tests & 30 \\
\hline ESE & 50 \\
\hline
\end{tabular}

The faculty has the freedom to design the ISE for students as per the course.

\section{Activities to be performed in PBL}

ISE evaluation of all the students was done using Problem Based Learning (PBL) assignment. Following activities were planned for the same.

1. Formation of team and identification of Vehicle:

Students were asked to form a team of 3 members each. Then they were given a deadline to submit the vehicle whose analysis with respect to vehicle dynamics is to be done for the entire semester as the syllabus progresses module wise from load transfer to ride characteristics.

2. Determination of $\mathrm{CG}$ position of the vehicle: In this activity, the students were asked to identify the position of Center of Gravity of the vehicle.

3. Calculations of dynamic axle loads of the vehicle: In this activity, students were asked to analyse the dynamic load transfer of the vehicle under different loading conditions and varying road conditions.

4. Analysis of acceleration performance of the vehicle:

In this activity all the group members were asked to analyse the acceleration performance of the vehicle.

5. Analysis of braking performance of the vehicle: 
In this activity all the group members were asked to analyse the braking performance of the vehicle as per load on the vehicle and on different types of roads.

6. Technical report on the working of the mechanism and the overall tasks carried out during the project:

In this activity, students were asked to make a small 4-5 page report on all the activities carried out during the entire course of the assignment.

7. Presentation of the whole project to an audience: In this activity, students were asked to present and share their experience.

All the activities carried out in the activity have been mapped to at least one program outcome defined by NBA.

Table 3: Mapping of project based learning activities to program outcomes defined by NBA

\begin{tabular}{|l|c|}
\hline \multicolumn{1}{|c|}{ Activity outcomes defined by NBA } \\
\hline $\begin{array}{l}\text { Formation of team } \\
\text { and identification of } \\
\text { Vehicle }\end{array}$ \\
\hline $\begin{array}{l}\text { Determination of CG } \\
\text { position of the } \\
\text { vehicle PO 11 }\end{array}$ \\
\hline $\begin{array}{l}\text { Calculations } \\
\text { dynamic axle loads of } \\
\text { the vehicle }\end{array}$ \\
\hline $\begin{array}{l}\text { Analysis PO } 2 \\
\text { acceleration } \\
\text { performance of the } \\
\text { vehicle PO 2 }\end{array}$ \\
\hline $\begin{array}{l}\text { Analysis of braking } \\
\text { performance of the } \\
\text { vehicle }\end{array}$ \\
\hline $\begin{array}{l}\text { Technical report on } \\
\text { the working of the } \\
\text { mechanism and the } \\
\text { overall tasks carried } \\
\text { out during the project }\end{array}$ \\
\hline $\begin{array}{l}\text { Presentation of the } \\
\text { whole project to an } \\
\text { audience }\end{array}$ \\
\hline
\end{tabular}

\section{Assessment and evaluation}

All these activities were assessed using a rubric. Rubric is divided into 9 activities which are marked for 10 marks each. In all, the students got a final score out of 90 marks which was then scaled back to 18 marks.

Rubric used for evaluation has been shown on the last page.

\section{E. Course Outcomes for the course}

The following course learning outcomes or course outcomes (COs) have been defined for the course Vehicle Dynamics as per the syllabus. Each of these COs are mapped to POs such that COs of all the courses in the program help for attainment of POs.

Table 4: Course Outcomes (COs) for the course Vehicle Dynamics

\begin{tabular}{|c|l|}
\hline $\begin{array}{c}\text { Course } \\
\text { Outcome } \\
(\mathrm{CO})\end{array}$ & \multicolumn{1}{|c|}{ Course Outcome Statement } \\
\hline CO 1 & $\begin{array}{l}\text { Calculate dynamic longitudinal and } \\
\text { transverse axle load transfer for a vehicle in } \\
\text { motion. }\end{array}$ \\
\hline CO 2 & $\begin{array}{l}\text { Determine the acceleration and braking } \\
\text { performance of a vehicle when provided with } \\
\text { specifications. }\end{array}$ \\
\hline CO 3 & $\begin{array}{l}\text { Evaluate handling characteristics of a vehicle } \\
\text { for a given set of data. }\end{array}$ \\
\hline CO 4 & $\begin{array}{l}\text { Apply ride concepts while designing a } \\
\text { suspension system for a vehicle. }\end{array}$ \\
\hline
\end{tabular}

\section{Experiences during implementation}

The planning for implementation of the PBL approach to assess and involve the students was done over a period of one and half months. This is predominantly during the break between the semesters.

The challenges faced during implementation of the activity were initial reluctance by students to accept the activity as an ISE. Also, this type of assessment needs extra efforts from students and the faculty as well. As compared to other forms of ISEs, this approach is time consuming and may also require help form some other faculty for evaluation. But, at the end of the activity, student feedback showed that all the effort and time invested is worth the learning gained by students.

The overall participation of students was found to be excellent. It being an activity based evaluation; students have enthusiastically worked on the problems for the selected vehicle and also presented it to the whole class. A total of 25 groups were formed and vehicle classes from sedan, sports cars, hatchback, etc were analysed for the activity.

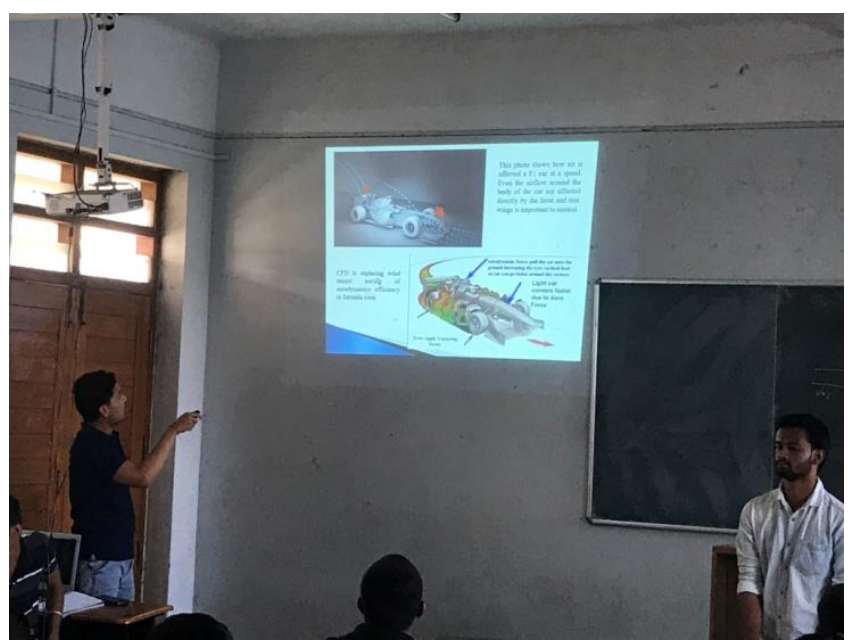

Fig. 1: Students presenting their findings to the entire class 
It was found that the overall $\mathrm{CO}$ attainment as compared to previous year was improved for three COs. A table showing actual improvement in the attainment of POs is shared in the conclusion.

\section{Conclusion}

Problem Based Learning is a very useful tool to encourage effective participation of students in the teaching learning process. It is a better option as compared to traditional evaluation methods like written tests and assignments. PBL improves the involvement of students and also is suitable for all types of students.

The table shows the comparison of $\mathrm{CO}$ attainment comparison for academic year 17-18 \& academic year 1819 based on performance of students in the ISE for both the years. Assignment based approach along with a quiz was used in the year 17-18 whereas PBL approach was used for the year 18-19. Attainment of all COs except CO2 shows considerable increase as compared to previous year.

Table 5: Comparison of CO attainment for AY 17-18 \& AY 18-19

\begin{tabular}{|c|c|c|}
\hline $\begin{array}{c}\text { Course } \\
\text { Outcome }\end{array}$ & $\begin{array}{c}\text { Attainment in } \\
\text { AY 17-18 }\end{array}$ & $\begin{array}{c}\text { Attainment in } \\
\text { AY 18-19 }\end{array}$ \\
\hline $\mathrm{CO} 1$ & $71 \%$ & $78 \%$ \\
\hline $\mathrm{CO} 2$ & $71 \%$ & $64 \%$ \\
\hline $\mathrm{CO} 3$ & $61.68 \%$ & $65 \%$ \\
\hline $\mathrm{CO} 4$ & $66.84 \%$ & $86 \%$ \\
\hline
\end{tabular}

\section{References:}

Blom A, and H. Saeki (2009), Employability and Skill Set of Newly Graduated Engineers in India, Bank Policy Research Working Paper Series, Volume 11. Du X. Y., and Kolmos A. (2006), Process Competencies in a Problem and Project Based Learning Environment, 35th SEFI Annual Conference: Engineering Education and Active Students, Uppsala, Sweden, 2006. Goel ,S (2006), Investigations on required core competencies for engineering graduates with reference to the Indian IT industry, European Journal of Engineering Education, 31:5, 607-617. Graaff E. D., and Kolmos A (2003)., Characteristics of Problem-Based Learning, Int. J. Eng. Ed. Vol. 19, No. 5, pp. 657-662.

Litzinger, T.A., Lattuca, L.R., Hadgraft, R.G.\& Newstetter, W.C. (2011).Engineering Education And The Development Of Expertise - Journal Of Engineering Education (pp. 123-150).100 (1). Rao (2006), Rao Committee Report, Faculty Development in India, July 2006. Shinde V., and A. Kolmos (2011a), Students Experiences in Aalborg PBL Model: A Case Study, SEFI Annual Conference, Lisbon, 27-30September 2011. Shinde V. (2011b), Relevance of the Problem and Project Based Learning (PBL) to the Indian Engineering Education, across the disciplines: research into best practice, 3rd International Research Symposium on PBL, Coventry University, U.K, 28-29 November 2011,489501. 
Rubrics for evaluation of PBL (Problem Based Learning) Assignment Final Year B. Tech. Auto. Engg.

Course - Vehicle Dynamic

Course Code - AE404

\begin{tabular}{|c|c|c|c|c|}
\hline \multicolumn{2}{|r|}{ Activity } & Level 1 (0-4) & Level $2(5-7)$ & Level 3(8-10) \\
\hline 1 & $\begin{array}{l}\text { Formation of Team \& } \\
\text { Identification of Vehicle }\end{array}$ & $\begin{array}{l}\text { Team formation and vehicle identification completed } \\
\text { after one week of the deadline. }\end{array}$ & $\begin{array}{l}\text { Team formation and vehicle identification } \\
\text { completed within one week of the deadline. }\end{array}$ & $\begin{array}{l}\text { Team formation and vehicle identification } \\
\text { completed before the deadline. }\end{array}$ \\
\hline 2 & $\begin{array}{c}\text { Determination of CG position of } \\
\text { the vehicle }\end{array}$ & Not able to identify the CG of the vehicle. & Able to identify the CG of the vehicle. & $\begin{array}{l}\text { Able to identify the CG of the vehicle with proper } \\
\text { explanation of the procedure. }\end{array}$ \\
\hline 3 & $\begin{array}{c}\text { Calculations of dynamic axle loads } \\
\text { of the vehicle }\end{array}$ & $\begin{array}{l}\text { Primitive knowledge about analysis of the dynamic } \\
\text { axle load transfer of any vehicle. }\end{array}$ & $\begin{array}{l}\text { Able to calculate the dynamic axle load } \\
\text { transfer of the vehicle. }\end{array}$ & $\begin{array}{c}\text { Able to analyse the dynamic axle load transfer of } \\
\text { the vehicle with proper explanation of all } \\
\text { equations. }\end{array}$ \\
\hline 4 & $\begin{array}{l}\text { Analysis of acceleration } \\
\text { performance of the vehicle }\end{array}$ & $\begin{array}{l}\text { Primitive knowledge about analysis of the dynamic } \\
\text { axle load transfer of any vehicle. }\end{array}$ & $\begin{array}{l}\text { Knows the procedure to calculate the } \\
\text { accleration performance of any vehicle. }\end{array}$ & $\begin{array}{l}\text { Able to analyse and explain the acceleration } \\
\text { performance of the vehicle. }\end{array}$ \\
\hline 5 & \begin{tabular}{|c|}
$\begin{array}{c}\text { Analysis of braking performance } \\
\text { of the vehicle }\end{array}$ \\
\end{tabular} & $\begin{array}{l}\text { Primitive knowledge about analysis of the dynamic } \\
\text { axle load transfer of any vehicle. }\end{array}$ & $\begin{array}{c}\text { Knows the procedure to calculate the braking } \\
\text { performance of any vehicle. }\end{array}$ & $\begin{array}{c}\text { Able to analyse and explain braking performance } \\
\text { of the vehicle. } \\
\end{array}$ \\
\hline 6 & $\begin{array}{c}\text { Analysis of ride characteristics of } \\
\text { the vehicle }\end{array}$ & $\begin{array}{l}\text { Primitive knowledge about analysis of the ride } \\
\text { characterictics of any vehicle. }\end{array}$ & $\begin{array}{l}\text { Knows the procedure to calculate the ride } \\
\text { characteristics of any vehicle. }\end{array}$ & $\begin{array}{l}\text { Able to analyse and explain the ride characteristics } \\
\text { of the vehicle. }\end{array}$ \\
\hline \multirow{2}{*}{7} & \multirow{2}{*}{$\begin{array}{c}\text { Technical report on the work } \\
\text { carried out through the semseter }\end{array}$} & Report is vague and content is incomplete. & $\begin{array}{l}\text { Report is somewhat accurate and content is } \\
\text { fairly complete. }\end{array}$ & $\begin{array}{c}\text { Report is complete with all relevant data/content, } \\
\text { is gramatically sound and has no formatting } \\
\text { errors. }\end{array}$ \\
\hline & & $\begin{array}{l}\text { Report is illogically organised and has gramatical and } \\
\text { formatting errors. }\end{array}$ & $\begin{array}{c}\text { Report is somewhat logically organised and } \\
\text { has marginal gramatical and formatting errors. }\end{array}$ & $\begin{array}{l}\text { Report has mention of all the tasks carried out } \\
\text { during the } \\
\text { entire duration of the assignemnt. }\end{array}$ \\
\hline \multirow{2}{*}{8} & \multirow{2}{*}{$\begin{array}{l}\text { Presentation of the whole project } \\
\text { to an audience }\end{array}$} & $\begin{array}{l}\text { No thought given to flow of presentation and } \\
\text { inclusion of very few activities carried out during the } \\
\text { assignment in the presentation. }\end{array}$ & $\begin{array}{c}\text { Hapazard flow of presentation and inclusion of } \\
\text { more than half the activities carried out during } \\
\text { the assignment in the presentation. }\end{array}$ & $\begin{array}{l}\text { Effective flow of presentation and inclusion of all } \\
\text { the activities carried out during the assignment in } \\
\text { the presentation. }\end{array}$ \\
\hline & & $\begin{array}{c}\text { Only few group members are aware of whole } \\
\text { presentation and other members are contributing } \\
\text { vaguely in the presentation. }\end{array}$ & $\begin{array}{l}\text { All the group members are aware of whole } \\
\text { presentation and contribute equally in the } \\
\text { delivery of presentation. }\end{array}$ & $\begin{array}{l}\text { All the group members are aware of whole } \\
\text { presentation and contribute equally in the } \\
\text { delivery of presentation. }\end{array}$ \\
\hline 9 & Question and Answer & $\begin{array}{l}\text { Less than } 50 \% \text { of questions posed by the audience } \\
\text { answered effectively by the group members. }\end{array}$ & $\begin{array}{c}\text { Between } 50-80 \% \text { of questions posed by the } \\
\text { audience answered effectively by the group } \\
\text { members. }\end{array}$ & $\begin{array}{l}\text { More than } 80 \% \text { of questions posed by the } \\
\text { audience answered effectively by the group } \\
\text { members. }\end{array}$ \\
\hline
\end{tabular}

Fig. 2 Rubric used for evaluation 